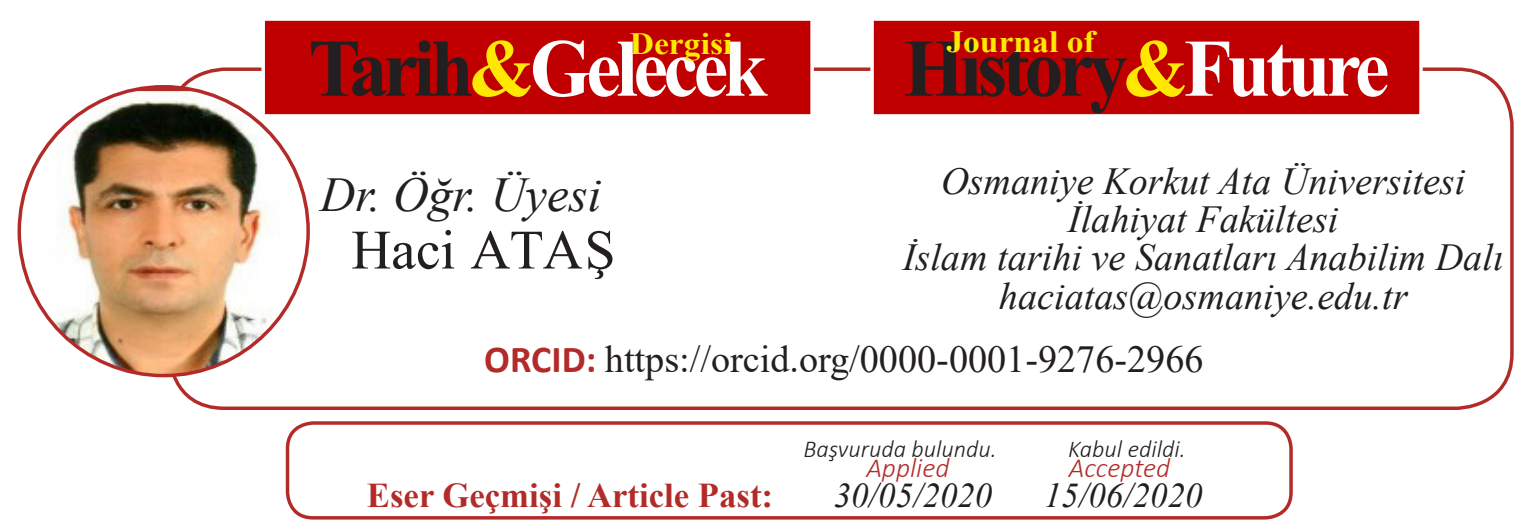

Araștırma Makalesi

DOI: http://dx.doi.org/10.21551/jhf.745535

Research Paper

Orjinal Makale / Orginal Paper

\title{
Hayzürân'ın Halife Hâdî ile İktidar Mücadelesi
}

\author{
The Struggle for Power of Khayzurān with the Caliph Hādī \\ Öz
}

Hayzürân'ın (öl. 173/789) geçmişi hakkındaki bilgiler oldukça yetersiz ve müphemdir. Mehdî (öl. 169/785) döneminde Băgdat'taki Abbâsî sarayına bir cariye olarak gelmiştir. Zekâsı ve baskın karakterinin yardımıyla kısa sürede Halife Mehdî'nin dikkatini çekmiş ve onun karısı olmayı başarmıştır. Halifenin karısı olduktan sonra da kendisine gösterilen müsamaha ve yüksek özgüveni sayesinde devlet yönetimine katılmaya başladi. Bir süre sonra da o zamana kadar hiçbir halife eşine nasip olmayan kudret ve itibara ulaştı. Mehdî'nin vefatından sonra halife olan büyük oğlu Mûsa el-Hâdî (öl. 170/786) zamanında da Hayzürân aynı otoriteyi ve gücü kullanmaya çalıştı. Ancak, babası ile zıt karaktere sahip olan Hâdî, annesinin devlet yönetimine müdahale etmesinden rahatsız oldu. Bu nedenle anne-oğul arasında ilk zamanlarda sözlü, sonraki zamanlarda ise düşmanca bir mücadele yaşandı. Bu çetin mücadeleyi Hayzürân kazandı ve kaynakların çoğunun aktarımına göre onu boğdurtarak öldürdü. Hâdî'nin ölümünden sonra da diğer oğlu Hârûn Reşî̀d'i (öl. 193/809) iktidara taşıdı. Hayzürân, yaklaşık üç yıl süren Hârûn Reşî̀d dönemindeki muktedir hayattan sonra 173/789 yılında Bağdat'da vefat etti. Onun sıra dışı kişiliği ve Abbâsî sarayına geldikten sonraki icraatları dikkate değer görüldü. Hayzürân'ın, Abbâsî iktidarında söz sahibi olan ilk kadın olması bile kanaatimizce onu araştırma konusu yapmak için geçerli bir sebeptir. Bu çalışmanın asıl gayesi Hayzürân ile oğlu Hâdî arasındaki siyasî mücadele ve bu mücadelenin dramatik sonucuna duyulan ilgidir.

Anahtar Kelimeler: İslâm Tarihi, Abbâsîler, Mehdî, Hayzürân, Hâdî. 


\section{Abstract}

Information about Khayzurān's (d. 173/789) past is quite insufficient and closed. She came to the Abbāsī palace in Baghdad as a concubine during the time of Mahdī (d. 169/785). With the help of her intelligence and dominant character she quickly caught the attention of the caliph Mahdi and managed to become his wife. After being the wife of the caliph she started to join the state administration thanks to his tolerance and her high selfconfidence. After a while she reached the power and reputation that had not been granted to any caliph wife until then. Khayzurān tried to use the same authority and power in the time of her eldest son, Hādī (d. 170/786), after Mahdī's death. However Hādī, who had the opposite character with his father, was disturbed by his mother's intervention in the state administration. For this reason there was a verbal struggle between the mother and son in the first times and an unfriendly struggle in the later times. Khayzurān won this tough fight and killed him by strangling according to the transfer of most sources. After Hādì's death she brought her other son Hārūn al-Rashīd (d. 193/809) to power. Khayzurān passed away in Baghdad in 173/789 after her ruling life in Hārün al-Rashïd which lasted about three years. Her extraordinary personality and her actions after coming to the Abbasid palace were considered remarkable. Even the fact that Khayzurān was the first woman to rule over Abbāsī's power is a valid reason to make her a research subject. Another aim of this study is the political struggle between Khayzurān and his son Hādi and the interest in the dramatic outcome of this struggle.

Keywords: Islamic History, Abbasids, Mahdī, Khayzurān, Hādī.

\section{Giriş}

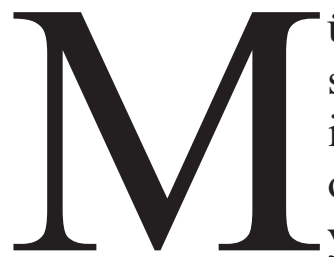

üslümanların Medine’ye hicret etmesi ile birlikte devletleşme süreci de başlamış oldu. Hz. Peygamber bu anlamda yeni devletin ilk başkanı (halifesi), komutanı ve kadısıydı. Devlet başkanı olarak onun en belirgin özelliği yönetim işlerini ashabıyla istişare halinde yürütmesidir. Vahiyle desteklenmesine rağmen Resûlullah (s.a.v.), istişare mekanizmasını hiçbir zaman terk etmemiştir. Hz. Peygamber ve ashabının üstesinden gelemediği hususlarda ise vahiy devreye girerek onlara yol göstermiştir. Medine'ye hicret ettikten sonra birçok kadınla evlenen Hz. Peygamber'in, bazı hususlarda onlarla istişare ettiği bilinmektedir. Özellikle kadınların özel durumları ve aile hayatı hakkında onların görüşlerine önem verdiğini biliyoruz. Bunların dışında Resûlullah (s.a.v.), tabiri caizse, bunaldığı zamanlarda da eşlerinden bazılarının fikirlerine ihtiyaç duymuştur. Meselâ, Hudeybiye barış görüşmeleri sonuçlandıktan sonra Hz. Peygamber, ashabından saçlarını tıraş etmelerini, kurbanlarını kesmelerini istemiş ancak ashap yaşadıkları hayal kırıklı̆̆ının etkisiyle Hz. Peygamber'in emrini yerine getirmede isteksiz davranmıştır. Bunun üzerine çok sinirlenen Resûlullah (s.a.v.) çadırına girmiş, çadırda kendisi ile birlikte Hudeybiye'ye gelen eşlerinden Ümmü Seleme'ye durumu anlatmış ve onun bu husustaki fikrini almak istemiştir. O da: "Ey Allah’ın Resûlü! Sen onlara bir şey söylemeden kalkıp tıraşını olur 
ve kurbanını kesersen onların da senin arkandan aynısını yapacağını umuyorum" demiştir. Durum, aynen Ümmü Seleme'nin dediği gibi olmuş ve ashap birbirleri ile yarışırcasına Hz. Peygamber'den sonra tıraşlarını olmuşlar, kurbanlarını kesmişlerdi. ${ }^{1}$ Hudeybiye'de yaşanan bu olayda Hz. Peygamber'in yeri geldiğinde eşlerini de istişareye dâhil etmekten geri durmadığını görüyoruz. Ancak Resûlullah'ın (s.a.v.), yönetimle alakalı bir mevzuda eşlerine danıştığına veya onların bu husustaki görüşlerini uyguladığına dair bir rivayete rastlanmamıştır. Meselâ, ordu komutanlarını tayinde; savaş, barış kararı gibi devlet yönetimiyle alakalı hususlarda eşlerinin görüşlerine başvurduğunu veya onların bu konuda görüş belirttiğine dair bir rivayet kaynaklarda görülmemiştir. Anlaşılan Resûlullah (s.a.v.), yönetimle ilgili konularda eşlerini veya başka kadınları karar mekanizmasına dâhil etmemiştir.

Dört halife döneminde devletleşme konusunda önemli gelişmeler yaşanmıştır. Özellikle Hz. Ömer döneminde devletin temel taşları yerine oturmaya başlamıştır. Yeni yerlerin fethedilmesi ile Müslümanlar, ilk defa farklı yönetim sistemleri ile tanışmıştır. İran topraklarının tamamının fethedilmesi, Bizans topraklarının da bir kısmının ele geçirilmesi ile birlikte İslam toplumunun farklı kültür ve dinlerle bir arada yaşamaya başladığını görüyoruz. Böylece Müslümanlar hem komşu ülkelerdeki yönetim sistemleri hem de bu sistemlerin artıları ve eksileri hakkında malumat edinmişlerdir. Köklü bir geçmişe sahip Sâsânîlerde ve Bizanslılarda kadınların devlet yönetimindeki rollerine dair bilgiler de muhtemelen Müslümanlara ulaşmıştır. Müslümanlarda ise devlet başkanlığı seçimi ve kurumsallaşma adına yapılan uygulamalar henüz yeni şekillenmeye başlamıştı. HulafâiRâşidîn döneminde halife adaylarının tespiti ve seçiminde kısmî bir seçim sisteminden bahsetmek mümkündür. Ancak bu sistemin içerisinde kadınların etkin bir şekilde rol üstlendiği görülmemektedir. Hz. Âişe'nin, Hz. Ali'nin halifeliğine karşı başlattığı siyâsi mücadele istisna olarak görülebilir. Hz. Âişe'nin bu mücadelesi devlet işlerine müdahaleden çok yönetime karşı bir isyan hareketi olarak yorumlanabilir. Eğer o, devleti yönetmeyi düşünseydi babasının halifeliği sırasında böyle bir girişimde bulunurdu.

Emevîlerin iktidara gelmesi yönetim tarzında köklü bir değişikliği de beraberinde getirmiştir. Hulafâ-i Râşidîn zamanında halife kısmî bir seçimle iş başına gelirken bu dönemden sonra halifelik artık babadan oğula geçen veya belli bir kabile üyeleri arasında dönüp dolaşan bir saltanat yönetimine dönüştü. Yaklaşık yüz yıl süren Emevî iktidarında kadınların yönetime müdahale ettiğine dair bir rivayet göremiyoruz. Bu dönemdeki iktidarlarda tamamen bir erkek hâkimiyeti yaşanmıştır. Kanaatimizce Bunun en temel sebeplerinden biri Arap toplumunda yaygın olan erkek hâkimiyetidir. İktidarlardaki erkek hakimiyeti o günün dünyasında bütün toplumlarda vardı ancak daha önce belirttiğimiz gibi Bizans $^{2}$ ve Sâsânî ${ }^{3}$ devletinin yönetiminde kısmî de olsa kadınların varlığından söz etmek mümkündür. Emevîlerde ise kadınların hiçbir surette idarede söz sahibi olamadıklarını görüyoruz. Mevâlı̂’nin de bu dönemde yönetimden uzak tutulması Araplar dışındaki

1 Ebû Abdillâh Ahmed b. Muhammed b. Hanbel, Müsned (Beyrut: Dâru İhyâu’t-Turâs el-Arabî, ts.), Hadis No: 18527.

2 Bk. Donald M. Nicol, Bizans’ın Soylu Kadınları, trc. Özden Arıkan (İstanbul: Tarih Vakfı Yurt Yayınları, 2001), 13-132.

3 Esko Naskali, "Sâsânîler”, Türkiye Diyanet Vakfi İslâm Ansiklopedisi (İstanbul: TDV yayınları, 2009), 36/174-176. 
unsurların iktidara gelmesinin önünü kapatmıştır. Halifeler de o dönemde genellikle Arap kadınlarla evlenmişler ancak onları yönetime dâhil etmemişlerdir. Halifeler, o dönemde Fars kültürü gibi kendi kültürlerinin dışındaki kadınlarla evlenmiş olsalardı, işte o zaman bu kadınların geleneklerinden getirdikleri yönetime müdahale etme tehlikesi (!) ile karş1 karşıya kalabilirlerdi.

Yukarıda bahsi geçen tehlike Abbâsîler dönemine gelindiğinde kendini gösterecektir. $\mathrm{Bu}$ dönemde artık halifeler Arapların dışında İran, Türk ve Berberî asıllı kadınlarla evlenmişler ve bu tehlikenin(!) kapısını aralamışlardır. Abbasilerin üçüncü halifesi olan Mehdî, cariyelerle evlenme geleneğini başlatmış, onları saraya alarak devlet çarkının işleyişi hakkında bilgi sahibi olmalarının önünü açmıştır. İşte o kadınlardan biri de Yemenli Hayzürân'dır. O, bir cariye olarak geldiği sarayda önce Mehdî’nin dikkatini çekmeyi başarmış sonra da onunla evlenerek sarayın sultanı olmuştur. Pek tabidir ki Arapların hâkimiyeti altındaki ülkelerde o dönemde kadınların yönetiminde söz söylemeleri sıra dışı bir olaydır. Bu yüzden ülkelerinin yönetiminde söz sahibi olan kadınlar her dönemde araştırmacıların ilgi odağı olmuştur. Dolayısıyla, kadın sultanları veya kadın yöneticileri konu edinen muhtelif çalışmalardan söz edilebilir. Bu çalışmalardan biri Bahriye Üçok tarafından İslam Devletlerinde Türk Nâibeler ve Kadın Hükümdarlar ismiyle kaleme alınan kitaptır. Bu alanda zikredilebilecek diğer bir çalışma ise tanınmış Faslı sosyolog ve yazar Fatima Mernissi'nin kaleminden çıkan ve M. Ali Kayabal ile Filiz Nayır'ın Türkçe'ye çevirdiği Hanım Sultanlar (İslam Devletlerinde Kadın Hükümdarlar) adıyla yayımlanan kitabıdır. Yine Zekeriya Kitapçı'nın yazdığı Abbâsî Hilafeti’nde Selçuklu Hatunları ve Türk Sultanları isimli kitap da bu alanda ortaya konmuş diğer bir çalışmadır. Yönetici kadınları ele alan Batı'daki çalışmalardan biri Donald Nicol'un yazdığı ve Özden Arıkan tarafından Türkçe'ye çevrilen Bizans'ın Soylu Kadınları adıyla yayımlanan kitabıdır. Hayzürân özelinde yapılan çalışmalar ise Mustafa Hizmetli'nin, Abbasiler Döneminde Kadının Siyasetteki Rolü: Harunürreşid'in annesi Hayzuran ve eşi Zübeyde Örneği isimli bildiriden ve Ahmet Güzel'in, Kadınların Siyasete Etkisi Bağlamında Hayzürân Örneği adıyla yayımlanan makaleden söz edilebilir.

Yukarıdaki çalışmaların bir kısmı belli bir isim üzerinde odaklanmadan genel olarak kadınların yönetimdeki hâkimiyetinden söz etmekte, bir kısmı ise Hayzürân'ın yönetime müdahalesinden bahsetmektedir. Bu çalışma ise, sadece Hayzürân üzerinde yoğunlaşmış spesifik bir çalışmadır. Hayzürân, kocası Mehdî ve küçük oğlu Hârûn Reşîd döneminde devlet yönetiminin dizginlerini eline geçirme noktasında herhangi bir sorun yaşamazken büyük oğlu Hâdî zamanında neden böyle bir sorun ile karşı karşıya kalmıştır? İslam Tarihi'ndeki ilk siyasî kadın figür olması bakımından Hayzürân'ın, oğlu Hâdî ile yaşadığı bu siyasî mücadele ve bu mücadelenin dramatik bir şekilde Hâdî aleyhinde sonuçlanması araştırılmaya değer görülmüştür. 


\section{Hayatı ve Kişiliği}

Hayzürân sözlükte, Hint kamışı, bambu gibi esnek bitkileri tanımlamak için kullanılan bir isimdir. ${ }^{4}$ Arap beldelerinde yetişmeyip Rum beldelerinde yetişen ve sapları esnek olan bir bitkiyi tanımlamak için de Hayzürân ismi kullanılmıştır. ${ }^{5}$ Bunun yanında, geminin arka tarafını tanımlamak için de kullanılan bir ifadedir. ${ }^{6}$

Hayzürân'ın kimliği konusundaki rivayetler muhteliftir. Babası Atâ'nın, Taberistan'da yapılan bir harpte esir edilerek Bağdat'a getirilen bir Yemenli olduğu rivayet edilir. ${ }^{7}$ Hayzürân'ın Berberî, ${ }^{8}$ hatta Türk olduğuna ${ }^{9}$ dair rivayetler de mevcuttur. Ancak onun, Yemenli bir ailenin yanında hizmetçi olarak çalışan kardeşi Gıtrîf'i Yemen'den getirterek buraya vali yapması Yemenli olduğu yönündeki rivayetleri desteklemektedir. Dolayısıyla Hayzürân'ın aslen Yemenli olduğu yönündeki rivayetler daha güçlü görünmektedir. ${ }^{10}$ Mehdî, güzelliğinden ve zekâsından etkilenerek 159/776 yılında Hayzürân'ı satın almış, sonra da azat ederek onunla evlenmiştir. ${ }^{11}$ Hayzürân, Mûsâ el-Hâdî ile Hârûn Reşîd'in anneleridir ${ }^{12}$ ve her ikisi de arka arkaya halifelik yapmıştır.

Hayzürân, kocası Mehdî’nin Abbâsî iktidarında bulunduğu sırada muhtemelen onun hoşgörülü ve müsamahakâr kişiliğinden de faydalanarak devlet işlerine müdahale etmeye başladı. ${ }^{13}$ Bir kadının devlet işlerine müdahil olması Arap toplumunda garipsenecek bir durumdu. Çünkü ne Emevîlerde ne de Abbasîlerde o ana kadar böyle bir müdahale görülmemişti. Öyle ki Hayzürân, bazen emir ve yasaklar ortaya koyarak bazen de verilen bir kararı bozarak yönetimdeki gücünü açık bir şekilde gösteriyordu. ${ }^{14}$ Hatta o kadar ileri gitmişti ki, Yemen'de bir kişinin evinde hizmetçi olarak çalışan kardeşi Gıtrîf'i önce yanına getirtmiş sonra da onu Yemen'e vali yapmıştı. ${ }^{15}$ Mehdî’nin diğer hanımlarımdan da çocuğu olmasına rağmen Hayzürân'ın, oğulları Hâdî ve Hârûn'u veliaht tayin ettirmesi onun devlet yönetimindeki hâkimiyetini net bir şekilde göstermektedir.

Mehdî’nin ani ölümünden sonra büyük oğlu Hâdî’nin halife olması Hayzürân açısından hayal kırıklığı olmuştur. Çünkü Hayzürân, Mehdî ölmeden önce diğer oğlu Hârûn'u, Hâdî’nin önüne geçirmek istemiş hatta bu konuda halifeyi ikna etmişti. Ancak Hayzürân,

4 Cemaleddin İbn Manzûr, Lisânü’l-Arab (Beyrut: Dâru Sâdır, h. 1414), 6/141.

5 İbn Manzûr, Lisânü'l-Arab, 4/237.

6 İbn Manzûr, Lisânü'l-Arab, 4/238.

7 Ebü'l-Hasen Alî b. el-Hüseyn b. Alî el-Mes'ûdî el-Hüzelî, Mürûcü’zz-zeheh, thk. Esad Dâgir (Kum: Dâru'l-Hicr, 1409), 3/324.

8 Süyûtî, Târîhu'l-Hulefâ', thk. Hamdi Timurtaş (y.y. Mektebetü Nizâr Mustafa el-Bâz, 1425/2004), 304.

9 Zekeriya Kitapçı, Abbâsî Hilafeti’nde Selçuklu Hatunları ve Türk Sultanları (Konya: 1997), 360.

10 Hayreddin ez-Ziriklî, el-A 'lâm (y.y. Dâru'l-ilm, 2002), 2/328.

11 Taberî, Târîhu Taberî, nşr. Dâru't-turâs (Beyrut: 1387), 8/121; İbnü'l-Cevzî, el-Muntazam fî̀ târîhi'l-ümemve'l-mülûk,thk. Muhammed Abdulkâdir Ata-Mustafa Abdulkâdir Ata (Beyrut: Dârü'l-kütübi'lilmiyye, 1412/1992), 8/229; Mes'ûdî, Mürûcü'z-żeheb, 3/313.

12 İbnü'l-Cevzî, el-Muntazam,9/346.

13 Taberî, Târîhu Taberî, 8/238.

14 Kasım Kırbıyı, "Hayzürân", Türkiye Diyanet Vakfı İslâm Ansiklopedisi (İstanbul: TDV Yayınları, 1998), 17/106-107.

15 Taberî, Târîhu Taberî, 8: 222; Hatîb el-Bağdâdî, Târîhu Bağdâd, thk. Beşşâr Avâd Ma'rûf (Beyrut: Dâru'l-garbi'l-islâmî, Beyrut 1422/2001, 1/395. 
halifenin zamansız vefatından dolayı bu emelini yerine getirememişti. ${ }^{16}$ Hayzürân’ın, Hâdî’yi istememesinin sebebi muhtemelen onunla iyi anlaşamayacağını düşünmesindendi. Çünkü Hâdî, babası gibi yumuşak huylu ve müsamahakâr değildi.

Halifeliğinin ilk aylarından itibaren Hayzürân ile Hâdî arasında adı konulmamış bir mücadele başladı. Hayzürân, tıpkı Mehdî zamanında olduğu gibi ülke yönetimine müdahale ediyordu. Ancak bu hususta babası ile aynı yerde durmayan Hâdî, annesinin müdahalelerine fazla sabır göstermedi. Böylece anne oğul arasında ilk zamanlarda zararsız sayılabilecek, sonraki zamanlarda ise hâsımâne bir şekle dönüşen bir mücadele yaşandi. Annesinin halife gibi davranmasına daha fazla tahammül edemeyen Hâdî onu, iktidardan tamamen uzaklaştırmanın yollarını aramaya başladı. Bu amacını gerçekleştirmek için bir gün annesine zehirli bir yemek gönderdi. Ancak yemeğin zehirli olduğunu hisseden Hayzürân onu bir köpeğe vermiş, köpek de bu zehirli yemeği yedikten sonra ölmüştü. ${ }^{17} \mathrm{Bu}$ olaydan sonra anne ile oğlunun arası iyice açılmış ve Hayzürân saraydan ayrılarak başka bir eve taşınmıştır. ${ }^{18}$

Hayzürân, son olaydan sonra oğlu Hâdî’ye açıktan savaş ilan etmiş, onu iktidardan indirip küçük oğlu Hârûn'u halife yapmak için harekete geçmiştir. Böylece Hayzürân, Hâdî’yi devre dişı ederek Hârûn Reşî̉d üzerinden ülkeyi yönetmeyi planlıyordu. Hâdî ise kardeşi Hârûn'u veliahtlıktan azledip yerine oğlu Cafer'i veliaht ilan ederek onun planını bozmak istiyordu. ${ }^{19}$ Anne oğul arasında yaşanan bu çetin mücadeleden Hayzürân galip ç1kmış, rivayetlerin çoğuna göre cariyelerinden birini oğlunu öldürmesi için görevlendirmişti. $\mathrm{Bu}$ iş için görevlendirilen cariye, Hâdî’yi hasta olduğu bir günde gece uyurken boğarak öldürmüştür. ${ }^{20}$

Mûsâ el-Hâdî'nin ölümünün ardından Hayzürân'ın diğer oğlu Hârûn Reşî̀ halife oldu. Tam da Hayzürân'ın istediği gibi kendisine asi olan oğlu gitmiş, onun yerine sözünden çıkmayacak diğer oğlu iktidar olmuştu. İktidarını güçlendirmek isteyen Hayzürân, Hâdî zamanında hapiste olan Yahyâ b. Hâlid el-Bermekî'yi önce özgürlüğüne kavuşturmuş sonra da geniş yetkilerle vezirliğe atanmasını sağlamıştır. ${ }^{21}$ Yahya ile eskiden beri iyi anlaşan Hayzürân, bu atamayla birlikte iktidardaki etkinliğini iyice arttırmıştır. Böylece oğlunun kendisine verdiği geniş yetki sayesinde Hayzürân gücünün zirvesine ulaşmıştır.

Hayzürân'ın iktidar hevesi fazla sürmedi. İkinci oğlu döneminde üç yıl kadar süren saltanatı 173/789 yılında Bağdat'ta vefat etmesi ile son buldu. Cenazesini oğlu Halife Hârûn

16 Taberî, Târîhu Taberî, 8: 168-69; Ebü'l-Fidâ’ İmâdüddîn İsmâîl b. Şihâbiddîn Ömer b. Kesîr, el-Bidâye ve'n-nihâye, thk. Abdullah b. Abdülmuhsin et-Türkî (Dâru Hicr littaba'ati ve'n-neşri ve't-tevzî've'l-i'lân, 1418/1997),13/550; İbnü'l-Cevzî, el-Muntazam, 8/316.

17 Taberî, Târîhu Taberî, 8/206; Muhammed b. Ali b. Muhammed İbnü'l-İmrânî, el-İnbâü fî târîhi’l-hulefâ, thk. Kâsım Sâmirâi (Kâhire: Dâru'l-âfâki'l-arabiyye, 1421/2001), 73.

18 İbn Kesîr, el-Bidâye ve'n-Nihâye, 13/556.

19 Taberî, Târîhu Taberî, 8/206; İbnü'l-Cevzî, el-Muntazam, 8: 335; Ebü'l-Hasen İzzüddîn Alî b. Muhammed b. Muhammed eş-Şeybânî el-Cezerî, el-Kâmil fi't-târîh, thk. Abdullah el-Kâdı (Beyrut: Dâru'l-kütübi'lilmiyye, 1415), 5/273.

20 Taberî, Târîhu Taberî, 8/206; İbnü'l-Cevzî, el-Muntazam, 8/335; İbnü'l-Esîr, el-Kâmil fi't-târîh, 5/273.

21 Taberî, Târîhu Taberî, 8/234; İbn Kesîr, el-Bidâye ve'n-nihâye, 13/562; İbnü'l-Cevzî, el-Muntazam, 8/321; İbn Haldûn, Târîhu İbn Haldûn, thk. Halil Şehâde (Beyrut: Dâru'l-Fikr, 1408/1988), 3/273. 
Reşîd kıldırdı. Defnedildiği yer Makberetü'l-Hayzürân olarak isimlendirilmiş²2 birçok müellif ve âlimin defnedildiği bu mezarlık günümüze kadar ulaşmıştır. Hayzürân, her ne kadar Hâdî zamanında ülkeyi istediği şekilde yönetemese de kocası Mehdî ve küçük oğlu Hârûn Reşîd zamanında ülkeyi bir sultan gibi yönetmiştir.

Hayzürân, devleti yönetme sevdasının dışında hayırseverliği ile de tanınmıştır. İhtiyaç sahiplerini gözetmiş, yetim ve yoksullara kol kanat germiştir. Hayzürân, 170/787 yılı Ramazan ayında hac farizasını yerine getirmiş ve bu esnada bol miktarda hediye dağıtmıştır. ${ }^{23}$ Bunların yanında Mekke'de Hz. Peygamber'in doğduğu evi tamir ettirerek mescide çevirmiştir. Kocası Mehdî'nin satın alarak kendisine bağışladığı Dâru'l-Erkam'1 da restore ettirmişti. Daha sonra burası Dâru'l-Hayzürân olarak tanınmıştır. ${ }^{24}$ İmam Evzâî'den bir süre fikıh dersi alan Hayzürân' $1 n^{25}$ İbn Abbas tarikiyle gelen bir de hadis rivayeti vardır. ${ }^{26}$

\section{Halife Mehdî Döneminde Hayzürân}

Abbâsîler döneminde saray teşkilatının gelişmesiyle birlikte Harîmu Dâri'l-Hilâfe olarak isimlendirilen harem de kurumsallaşmaya başlamıştır. Hareme getirilen köle ve cariyeler ya savaşlarda ele geçirilen esirlerden ya da halifelere sunulan hediyelerden oluşuyordu. Abbâsîler döneminden itibaren saraylarda cariyelerin varlığından söz edilmekle birlikte onların halifelerin özel hayatlarına yön verdiklerini söylemek güçtür. İlk halife esSeffâh'ın, kendisini metheden şairlere cariye hediye ettiği nakledilir. İkinci Abbâsî halifesi Mansur'un da siyasî amaçlarla cariye hibe ettiği bilinmektedir. Mansur, cariyelerin haklarını gözetmiş ve onlarla evlenmeyi teşvik etmiştir. ${ }^{27}$

Mansur, oğlu Mehdî'ye ilk cariyesi Muhayyat'ı henüz onlu yaşların başında hediye etmişti. Mehdî, Abbâsîler döneminde çocuk edinmek için cariye satın alan ilk halifedir. Bu amaçla aldığı cariye kısa süre sonra ölünce başka bir cariye satın aldı. Bu cariye oğulları Hâdî ve Hârûn'un anneleri olan Hayzürân'dır. Mehdî, Mansur'un vefatından sonra 158/775 yılında halife olmuş bundan bir yıl sonra da cariyesi Hayzürân'1 azad ederek onunla evlenmiştir. ${ }^{28}$ Halife olduğunda 33 yaşında ${ }^{\text {rq }}$ olan Mehdî, Hayzürân ile evlendiğinde 34 yaşında olmalıdır.

Üçüncü Abbasî halifesi Mehdî döneminde devletleşme süreci tamamlanmış, dâhili problemler büyük oranda bertaraf edilmişti. Bu müspet şartlar altında iktisadi yönden de bir rahatlama yaşanmıştı. Siyasî, ekonomik ve sosyal hayattaki gelişmeler sayesinde Mehdî, Abbasîlerde normalleşmeyi sağlayan halife olarak kabul edilmiştir. On yıllık iktidarı boyunca kendisinden önceki halifelerin sert politikalarını terk ederek daha hoşgörülü ve

Taberî, Târîhu Taberî, 8/238.

Taberî, Târîhu Taberî, 8/235; İbnü'l-Cevzî, el-Muntazam, 8/337.

İbnü'l-Cevzî, el-Muntazam,2/380; Salahaddîn Halîl Safdî, el-Vâfibi'l-vefeyât, thk. Ahmet Arnavut ve Türkî Mustafa (Beyrut: Dâru İhyâi't-turâs, 1420/2000), 8/235.

İbnü'l-Esîr, el-Kâmil fi't-târîh, 5/272; Ziriklî, el-A'lâm, 2/328. İbn Kesîr, el-Bidâye ve’n-nihâye, 13/570; İbnü'l-Cevzî, el-Muntazam,8/346. Mehmet Nâdir Özdemir, "Abbâsîler'de Kölelik”, İslâm Tarihi ve Medeniyeti (İstanbul: Siyer Yayınları, 2018), 6/138.

İbn Kesîr, el-Bidâye ve'n-nihâye, 13/478; İbn Abdürabbih, el-İkdü'l-Ferîd (Beyrut: Dâru'l-kütübi'lilmiyye, 1404), 5/372.

İbn Kesîr, el-Bidâye ve'n-nihâye, 13/541-42. 
sosyal barışı sağlamaya yönelik bir siyasî anlayış benimsemiştir. ${ }^{30}$

Abbâsîler döneminde sosyal hayatta yaşanan gelişmeler saray hayatına da yansımıştır. Ülkedeki refah seviyesinin artışı Mehdî’nin aile hayatını da olumlu yönde etkilemiş, bir kısmı cariye olmak üzere birçok evlilik yapmıştır. Bu cariyelerden biri de Hayzürân'dır. Yemenli cariye kendisine sunulduğunda Mehdî, onun yüzünü beğenmiş ancak vücudunun sıskalığından hoşlanmamış ve ona: "Ey cariye! Son derece güzel bir yüzün var ancak keşke bu kadar zayıf olmasaydın!” demiş, Hayzürân ise ona şöyle cevap vermişti: “Ey mü’ minlerin emîri! Şu vücuttan ziyade onların bağlı olduğu yere muhtaçsın. Vücudu görmesen de olur." Bu akıl dolu cevabını beğenen Mehdî, onu satın almıştı. Sonrasında Hayzürân halifenin gözdesi haline gelmiş ve itibar sahibi olmuştur. ${ }^{31}$

Hayzürân, kocası Mehdî’nin yanındaki itibarını devlet yönetiminde de kullanmaya başladığından ülkeyi halifeyle birlikte yönetmeye başlamıştır. Saraydaki komutanlar ve yöneticiler Mehdî’ye gösterdikleri hürmet ve saygıyı Hayzürân'a da gösterirlerdi. Hayzürân'ın saraydaki ağırlığı o kadar fazlaydı ki Mehdî’nin onun görüşünü almadan hiçbir şey yapmadığı rivayet edilir. ${ }^{32}$ Hayzürân, ülkenin gidişatı hakkında söz sahibi olmasının yanında oğullarının geleceği hakkında da kocası Mehdî’yi yönlendirmeye başladı. Daha önce ikinci halife Mansur tarafından veliaht ilan edilen Îsa b. Mûsa, oğullarının önünde duran en büyük engellerden biriydi. Mehdî'den sonra oğullarının halife olabilmesi için Îsa'nın ikna edilmesi gerekiyordu. Başlangıçta veliahtlıktan çekilmeye yanaşmayan Îsa, Mehdî'nin ona önemli miktarda arazi ve10 milyon dirhem de para teklif etmesiyle halife adaylı̆̆ından çekilmiştir. ${ }^{33}$

Yeri geldiğinde eğlenmekten, şairleri ve şarkıcıları dinlemekten geri durmayan Mehdî'nin şiirle de arası iyiydi. Belki de Mehdî’nin Hayzürân’1 bu kadar sevmesinin bir sebebi de karısının da şiire tutkun olmasıdır. ${ }^{34}$ Mehdî, Hayzürân hacca gittiğinde ${ }^{35}$ Mekke'deki karısına olan özlemini şu şiirle dile getirmiştir:

$$
\begin{aligned}
& \text { نحن في غاية السرور ولكن ... ليس إلا بكم يتم السرور } \\
& \text { عيب ما نحن فيه با أهل ودي ... أنكم غيب ونحن حضور } \\
& \text { فأجدوا في السير بل إن قدرنم ... أن تطيروا مع الرياح فطيروا } \\
& \text { فأجابته أو قالت لمن أجابه: } \\
& \text { قد أتانا الذي وصفت من الثو ... ق فكدنا وما فعلنا نطير } \\
& \text { ليت أن الرياح كن يؤدي ... ن إليكم ما قد يجن الضمير } \\
& \text { لم أزل صبة فإن كنت بعدي ... في سرور فدام ذاك السرور } 36
\end{aligned}
$$

30 Âdem Apak, Ana Hatlarıyla İslâm, Tarihi Abbâsîler Dönemi (İstanbul: Ensar Yayınları, 2016), 110-111.

31 İbn Kesîr, el-Bidâye ve'n-nihâye, 13/570; İbnü'l-Cevzî, el-Muntazam, 8/346.

32 Taberî, Târîhu Taberî, 8/238.

33 Ya'kûbî, Târîhu Ya'kûbî, (y.y. Matbaul Berîd, 1883), 476; Taberî, Târîhu Taberî, 8/125; İbnü’l-Esîr, el-Kâmil fi't-ârîh, 5/234.

34 Şehabeddin Muhammed İbşîhî, el-Müstețraf, thk. Müfîd Muhammed Kamîha (Beyrut: Dâru'l-kütübi'lilmiyye, 1986), 2/121.

35 Taberî, Târîhu Taberî, 8/235.

36 İbn Kesîr, el-Bidâye ve’n-nihâye, 13/570-71; İbn Asâkir, Târîhu Dımeşk, thk. Amr b. Garâme (y.y. Dâru'l- 
"Biz sevinç içindeyiz ama, sevincimiz ancak sizinle tamamlanır. Bir tek eksiğimiz vardır ey sevgilim, siz uzaklarda biz buradayı. Hızla buraya gelin, eğer mümkünse rüzgârla birlikte uçarak gelin”. Hayzürân da Mehdî̀ye şu sözlerle karşıllık vermiştir: "Anlattı̆̆ı özlemini anladık. Neredeyse uçacaktık ama uçamadık. Keşke rüzgârlar kalbimizdeki aşkı ve özlemi size ulaşttrabilseler. Senin için hep özlem duyuyorum ama benden uzaktayken sen yine de sevinç içinde olabiliyorsan sevincin devam etsin!'”37

Anlaşılan Hayzürân, Mehdî’nin kendisi yanında yokken sevinçli olmasını kabullenmemiş ve "benden uzaktayken sevinçli olabiliyorsan öyle devam et!" diyerek sitemini dile getirmiştir.

Meşhur siyer âlimi Vâkıdî'den nakledilen bir rivayet, Mehdî ile Hayzürân arasında yaşanan bir tartışmayı haber vermektedir. Vâkıdî bir gün Mehdî’nin yanına gitmiş ve ona birkaç hadis nakletmiştir. Naklettiği hadisleri yazdıktan sonra Mehdî, kadınlarından birinin odasına gitmiş sonra öfkeli bir şekilde tekrar Vâkıdî’nin yanına dönmüştür. Bunun üzerine Vâkıdî: “Sana ne oldu ey mü'minlerin emîri?” demiş, o da: "Hayzürân'ın yanına gittim, bana diklendi. Ayağa kalkıp beni tartakladı ve 'Senden hiç hayır görmedim' dedi. Ey Vâkıdî! Allah'a yemin ederim ki ben onu bir köle tüccarından satın aldım. Benim yanıma gelince makam ve mertebe sahibi oldu, itibar kazand. Benden sonra da her iki oğlunu (Hâdi ve Hârûn) veliaht ilan etti" diyerek, serzenişte bulundu. Bu sözlerden sonra Vâkıdî: Ey mü'minlerin emîri! Resûlullah (s.a.v.), bu gibi kadınlar hakkında şöyle buyurmuştur: "Onlar, kerem sahibi kimseleri mağlup ederler. Ama alçak karakterli erkekler de onları mağlup ederler." Resûlullah (s.a.v.), başka bir hadisinde şöyle buyurmuştur: "Sizin en hayırlınız, ailesine hayırlı olanınızdır. Ben de sizin, ailesine en hayırlı olanınızım. Doğrusu kadın eğri kaburgadan yaratılmıştır. Onu düzeltmeye kalkarsan kırarsın." Vâkıdî, Hz. Peygamber'den yukarıdaki sözleri aktardıktan sonra Mehdî ona, 2.000 dinar verilmesini emretti. Vâkıdî, rivayetine şöyle devam etmektedir: "Oradan ayrılıp evime gittiğimde kapıya varır varmaz Hayzürân'ın elçisi bana yetişti ve bana bir miktar para ve birkaç takım elbise verdi. Hayzürân bana, bu para ve elbiseleri bir şükran ifadesi olarak göndermişti." ${ }^{38}$ Anlaşılan Vâkıdî'nin aktardığı hadisler Mehdî üzerinde olumlu etki bırakmış ve Hayzürân'a karşı şefkatli davranmış olmalı ki, Mehdî’nin ardından Hayzürân da Vâkıdî'yi hediyelere boğmuştur. Vâkıdî'nin rivayetinden çıkarabileceğimiz bir sonuç da Hayzürân'ın halife kocasına karşı bazen şımarıkça davrandığıdır. Onu köle olarak sarayına alıp taltif eden ve ona itibar kazandıran birine karşı haddini aşan bir tavır takınmıştır. Anlaşılan Hayzürân, baskın karakterinin yansımalarını halife kocası üzerinde de göstermekten çekinmemiştir.

Hayzürân'ın Mehdî üzerindeki hâkimiyeti yukarıdaki örnekle sınırlı kalmamıștır. Bilindiği gibi Mehdî, Hayzürân'ın büyük oğlu Hâdî’yi kendisinden sonraki halife adayı olarak ilan etmişti. Ancak Hayzürân, muhtemelen daha iyi anlaşacağını umduğu küçük oğlu Hârûn'un ilk halife adayı olmasını istiyordu. Bu konuda kocası Mehdî’yi de ikna

fikr, 1415/1995), 53/445.

37 Şiirin Türkçesi için bk. İbn Kesîr, el-Bidâye ve’n-nihâye, trc. Mehmet Keskin (İstanbul: Çağrı Yayınları, 1995), 10/275. 
etmeyi de başarmıştı. Mehdî bu kararını oğlu Hâdî̀ye bir elçi ile bildirmiş ancak Hâdî bu kararı takmadığı gibi elçiyi de döverek geri göndermiştir. ${ }^{39}$ Bunun üzerine, o sırada Cürcân'da bulunan Hâdî'nin üzerine yürümek için yola çıkmış ancak Mehdî Cürcân'a ulaşamadan 169/785 yılında Mâsebezân'da ani bir şekilde vefat etmiştir. Onun vefatıyla ilgili rivayetlerde farklıdır. Bu rivayetlerden birine göre o, av esnasında yaşanan bir kaza sonucu vefat etmiştir. ${ }^{40}$ Başka bir rivayete göre Mehdî’nin cariyelerinden biri kendisine rakip olarak gördügü başka bir cariyeyi öldürmek için yemeğine zehir katmış, Mehdî de yanlışlıkla bu yemekten yiyerek ölmüştür. ${ }^{41}$ Vefat ettiğinde 43 yaşlarında olan Mehdî 10 sene bir ay halifelik yapmıştır. ${ }^{42}$ Mehdî'nin, Hayzürân'ın etkisi ile Hârûn'u diğer oğlu Hâdî’nin önüne geçirme teşebbüsü onun siyasî bir hatası olarak yorumlanmıştır. ${ }^{43}$

Devlet işlerine yatkınlığı ile bilinen Hayzürân, yöneticiliğindeki maharetine sosyal alandaki faaliyetlerini de eklemiștir. Hacca gittiğinde Mekke'de Darü'l-Hayzürân diye bilinen meşhur evi satın alarak Mescid-i Haram'a eklemiştir. Onun bolluk içinde bir hayat yaşadığı, çiftliklerinin yıllık gelirinin yüz binlerce dirheme ulaştığı rivayet edilir. ${ }^{44}$

\section{Mûsâ el-Hâdî Döneminde Hayzürân}

Mehdî, vefatına sebep olan Cürcân yolculuğuna çıkarken yerine azatlısı Rebî'yi vekil bırakmış, küçük oğlu Hârûn'u da yanına almıştı. ${ }^{45}$ Mehdî’nin vefatının ardından Hârûn, defin işlerini tamamladıktan sonra Bağdat'a döndü. Annesi Hayzürân ise, Rebî ve Yahya'yı halifelik konusunda istişarede bulunmak için yanına çağırdı. Yapılan istişare sonucunda daha önce Mehdî tarafindan veliaht ilan edilen Hâdî'ye biat edilmesine karar verildi. ${ }^{46}$ Hârûn, bu haberi ülkenin çeşitli vilayetlerine mektuplar yazarak ilan etti. O sirada Cürcân'da bulunan Hâdî’ye bir elçi ile haber verildi ve Bağdat'a gelerek görevine başlaması istendi. Böylece yeni halife Hâdî, 20 günde posta bineği ile Bağdat'a ulaşarak burada kendisine biat ald..$^{47}$

Hâdî, babası Mehdî’nin 169/785 yılında ani vefatının ardından Abbâsî devletinin dördüncü halifesi oldu. Mehdî, önce büyük oğlu Hâdî’yi veliaht ilan etmiş, ancak Hayzürân'ın da etkisiyle bu kararını yeniden gözden geçirmiş küçük oğlu Hârûn Reşîd'i onun önüne geçirmek istemiştir. Ancak Mehdî’nin ömrü bu kararı uygulamaya yetmemişti. Bazı devlet adamları Mehdî’nin vefatından sonra Hârûn Reşîd'e biat etmeye niyetlenmiş ancak yapılan istişare sonucu ilk olarak veliaht ilan edilen Hâdî'ye biat edilmiştir. ${ }^{48}$

39 Taberî, Târîhu Taberî, 8/168; İbn Kesîr, el-Bidâye ve’n-nihâye, 13/553.

40 Taberî, Târîhu Taberî, 8/169; İbnü'l-Esîr, el-Kâmil fi't-târîh, 5/259; İbn Kesîr, el-Bidâye ve’n-nihâye, $13 / 551$.

41 Taberî, Târîhu Taberî, 8/168-69; İbn Kesîr, el-Bidâye ve’n-nihâye, 13/551; İbnü'l-Cevzî, el-Muntazam, 8/316.

42 Apak, Ana Hatlarlyla İslâm Tarihi, 110-111.

43 Ahmet Güzel, "Mehdî ve Hâdî Dönemleri”, Íslam Tarihi ve Medeniyeti (İstanbul: Siyer Yayınları, 2018), 5/125.

44 İbn Kesîr, el-Bidâye ve’n-nihâye, 13/571; Mes'ûdî, Mürûcü’ż-zeheb, 3/337.

45 Taberî, Târîhu Taberî, 8/187.

46 İbn Kuteybe, el-Maârif, thk. Servet Ökkâşe (Kâhire: 1992), 380; Taberî, Târîhu Taberî, 8/188.

47 Taberî, Târîhu Taberî, 8/188-89. Taberî, Târîhu Taberî, 8/187; İbnü'l-Cevzî, el-Muntazam, 8/305; İbnü'lEsîr, el-Kâmil fi't-târîh, 5/264.

48 İbn Kesîr, el-Bidâye ve'n-nihâye, 13/553. 
Hâdî iktidara geldikten sonra babası zamanında olduğu gibi devlet yönetimine müdahil olan annesini ilk aylarda görmezden geldi. Devlet erkânının ve halkın Hayzürân'a gösterdiği alakaya sabretti. Ancak bir süre sonra annesinin müdahalelerine dayanamayan Hâdî, onu şu sözlerle uyarmak zorunda kaldı: "Devleti, annesi tarafindan yönetilen halifeye yazıklar olsun! Allah'a yemin ederim ki, bundan böyle kapında iş takip eden herhangi bir görevliye rastlarsam onun boynunu vurup mallarına el koyacağım. Bu ne biçim bir hal ki, sabah akşam demeden birtakım insanlar kapının eşiğini aşındırıyor. Senin yün eğirecek iğin, okuyacak Mushaf'ın ve oturacak evin yok mu? Sakın bir daha kapını Müslümanlara ve zimmilere açmayasın!" 49

Ancak Hayzürân'ın devlet işlerine müdahil olmaktan vazgeçmeye niyeti yoktu. ${ }^{50}$ Hayzürân'ın, Hâlise adında bir cariyesi vardı. İnsanlar istek ve şikayetlerini önce Hâlise'ye bildirir o da bunları Hayzürân'a iletirdi. Hayzürân, kendisine gelen bir hacet için Hâlise'yi iki defa Hâdî'ye gönderdi. Ancak Hâdî, annesinin talebini geri çevirdi. Bunun üzerine Hayzürân, Hâdî’ye bizzat kendisi giderek: "Bu hacet Abdullah b. Mâlik içindir. Çünkü ben ona kefil oldum. Verdiğim sözün yerine getirilmemesinden utanırım" dedi. Hâdî ise annesine: "Sen neden onlara söz veriyorsun ve hacetlerine kefil oluyorsun? Melik mertebesindeki insanlar senin kapında ne arıyorlar? Senin yapman gereken şey evde eğe ve pamuk ile uğraşmak, Kur'an ve ibadetle meşgul olmaktır. Melikleri selamlamak, insanların hacetlerini gidermek ve kapıda nakipler tutmak senin işin değildir. Artık senin kapına kimsenin geldiğini görmeyeyim" diyerek sert bir şekilde tepkisini dile getirdi. Oğlunun bu sert sözleri üzerine Hayzürân ağlayarak odadan dışarı çıktı. ${ }^{51}$

Hâdî, annesi ile arasında geçen bu sert diyalogdan sonra idarecilerini çağırttı ve onlara: "Söyleyin bakalım bana sizin annelerinizi mi insanlardan saklamak gerekir yoksa benim annemi mi?" Onlar da: "Sizin annenizi" dediler. Hâdî onlara: "Annelerinizin nerede olduğunu ne dediklerini ne yaptıklarını insanların bilmesi gerekir mi? Meclislerde, pazarlarda annenizin adının konuşulması doğru mudur? dedi. Onlar da: "Doğru değil" dediler. Bunun üzerine Hâdî: "Öyleyse sizler niçin işlerinizi halletmek için anneme gidiyorsunuz? Evlerde, mahallelerde halifenin anası şöyle dedi böyle iş yaptı, diyorsunuz? Neden sadece onu bilip onunla iş tutuyorsunuz? Niçin onun kapısından ayrılmıyorsunuz?" dedi. Bu sözlerden sonra yöneticiler Hayzürân ile alakalarını kestiler. ${ }^{52}$

Annesi ile arası iyice açılan Hâdî, halifeliğinin selameti için artık onun ortadan kaldırılması gerektiğini düşünüyordu. Bu amaçla bir gün bir tabak pilav1 zehirleyerek annesine gönderdi. Ancak Hayzürân, pilavın zehirli olmasından şüphelendi ve onu bir köpeğe yedirdi. Köpek, pilavı yer yemez zehirlenerek öldü.. ${ }^{53}$

Hayzürân ile halife oğlu Hâdî arasında bu tatsız olaylar yaşanırken bir gün kardeşi Hârûn Reşîd, Hâdî’nin huzuruna geldi. Onun sağ tarafında uzak bir yere oturdu. Hâdî

50 Ebû Ca‘fer Safiyyüddîn Muhammed b. Alî b. Tabâtabâ el-Hasenî el-Alevî (İbnü’t-Tiktakā), el-Fahrî, (Beyrut: Dâru Sâdır, ts.), 191.

51 Taberî, Târîhu Taberî, 8/205-206; İbnü'l-Esîr, el-Kâmil fi't-târîh, 5/273.

52 Taberî, Târîhu Taberî, 8/207; İbnü'l-Esîr, el-Kâmil fi't-târîh, 5/273.

53 Taberî, Târîhu Taberî, 8/206; İbnü'l-İmrânî, Târîhi’l-Hulefâ, 1421/2001), 73. 
ona uzun süre baktıktan sonra şöyle dedi: "Ey Hârûn! Gerçekten veliaht olmak istiyor musun?" Hârûn: "Evet, vallahi istiyorum. Eğer veliaht olur sonra da halifeliğe geçersem senin münasebetini kopardığın kimselerin gönüllerini kazanacağım. Kendilerine haksızlık ettiğin kimselere adaletle davranacağım. Kızlarını da oğullarımla evlendireceğim" dedi. Hâdî kardeşinin bu sözleri üzerine: "Zaten ben de senden bunları bekliyorum" şeklinde karş111k vermiştir. ${ }^{54}$

Hâdî, annesine ve diğer yöneticilere halifenin kim olduğunu göstermek istiyordu. Bu yüzden annesini kesin olarak devlet idaresinden uzaklaştırmak niyetindeydi. Bu gaye ile annesinin arkasında durduğunu düşündüğü kardeşi Hârûn Reşî̉'i veliahtlıktan azletmek istedi. Amacı onun yerine oğlu Cafer'i veliaht ilan ederek karşı bloğu etkisiz hale getirmekti. Bu niyetini bazı komutanlarına açan Hâdî, onlardan da destek bulunca kararını açıklamak üzere iken vefat haberi gelmişti. ${ }^{55}$ Muhtemelen Hayzürân bu durumu öğrenmiş ve Hâdî’nin ölüm fermanını da bu karardan sonra vermişti. Çünkü Hâdî bu planını uygulayamadan vefat etmiştir. Eğer Hârûn veliahtlıktan azledilirse Hayzürân'in devleti yönetme arzusu tamamen sona erebilirdi. Çünkü Hâdî, annesinin yetkilerini tamamen kısıtlamış ve: "Herhangi bir emir veya komutan bundan böyle eğer işlerini yaptırmak için annemin kapısına giderse onun boynunu vururum ve onun için şefaat de kabul etmem" diyerek annesine karşı kesin bir tavır almışt. ${ }^{56}$

Hâdî, kardeşi Hârûn ile yaptığı bu görüşmeden sonra Musul'a gitti. Orada hastalanınca geri döndü. ${ }^{57}$ Musul'dan döndükten sonra da 170/786 y1lında Rebiyülevvel ayının ortasında Cuma gecesi İsâbâd'da vefat etti. ${ }^{58}$ Onun genç yaşta beklenmedik bir şekilde vefat etmesi şüpheyle karşılanmıştır. Vefat sebebi bazı kaynaklara göre karnında çıkan bir çıbandı. Bu çıban yarıldı ancak ne yemek yiyebildi ne de bir şey içebildi. Bir süre sonra da bu çıban nedeniyle öldü. ${ }^{\circ 9}$ Kaynaklarda geçen başka bir rivayete göre Hâdî, annesinin bir komplosu sonucu öldürülmüştür. Bu rivayete göre Hâdî, kardeşi Hârûn'u veliahtlıktan azledip yerine kendi oğlu Cafer'i getirmek isteyince Hayzürân buna engel olmak için cariyelerinden birini görevlendirerek hasta yatağındaki Hâdî̀ yi yastıkla boğdurmuştur. ${ }^{60}$ Başka bir rivayete göre Hâdî, kardeşi Hârûn'u veliahtlıktan azletmeye karar verince annesi Hayzürân tarafindan zehirletilerek öldürülmüştür. ${ }^{61}$ Evzaî'den nakledilen diğer bir rivayete göre Hayzürân, oğlu Hârûn'a bir kötülük yapmasından korktuğu için Hâdî’yi zehirleterek öldürtmüştür. Çünkü Hâdî, halife iken annesini devlet işlerinden uzaklaştırmış, gözdelerinden Hâlise’yi de kendi

54 Taberî, Târîhu Taberî, 8/211; İbn Kesîr, el-Bidâye ve’n-nihâye, 13/557.

55 Taberî, Târîhu Taberî, 8/206; İbnü'l-Esîr, el-Kâmil fi't-târîh, 5/270; İbn Kesîr, el-Bidâye ve’n-nihâye, $13 / 556$.

56 İbn Kesîr, el-Bidâye ve’n-nihâye, 13/556.

57 Taberî, Târîhu Taberî, 8/212; İbnü'l-Esîr, el-Kâmil fi't-târîh, 5/272; İbn Kesîr, el-Bidâye ve’n-nihâye, $13 / 557$.

58 İbn Kesîr, el-Bidâye ve'n-nihâye, 13/557.

59 Taberî, Târîhu Taberî, 8/205; İbnü'l-Esîr, el-Kâmil fi't-târîh, 5/272.

60 Taberî, Târîhu Taberî, 8/206; İbnü'l-Cevzî, el-Muntazam, 8/335; İbnü'l-Esîr, el-Kâmil fi't-târîh, 5/273.

61 İbn Kesîr, el-Bidâye ve’n-nihâye, 13/557; Zehebî, Târîhu'l-İslâm, thk. Ömer Abdusselam (Beyrut: Dâru'lkitâbi'l-arabî, Beyrut 1413/1993), 10/40; Süyûtî, Târîhu'l-Hulefầ, 304; Zehebî, Siyerua 'lâmi'n-nübelâ', thk. Şuayp Arnavut liderliğinde bir grup muhakkik (y.y. Müessesetü’r-risâle, 1405/1985), 7/443. 
yakınına almış ve onu itibarlı kılmışt1. ${ }^{62}$ Hâdî'nin öldügü gece Hayzürân'ın şöyle dediği rivayet edilir: "Biz bu gece bir halifenin öleceğini, birinin halife olacağını, bir diğerinin de doğacağını konuşmuştuk. Hâdî öldü, Hârûn halife oldu, Me'mun da dünyaya geldi." ${ }^{63}$ Hâdî, 170/786 yılında vefat ettiğinde henüz 23 yaşındaydı ve yaklaşık 14 ay halifelik yapmıştı. ${ }^{64}$

\section{Hârûn Reşîd Döneminde Hayzürân}

Hâdî'nin vefat ettiği gece 170/786 yılında Rebiyülevvel ayının ortasında Cuma gecesi Hârûn Reşîd'e biat edildi. Hârûn Reşîd halife olduğunda 22 yaşındaydı. Halifeliği döneminde Hâdî’nin hapse attığ 1 Yahya b. Hâlid b. Bermek'i hapisten çıkardı ve onu vezir yaptı. Kaynaklara göre Hâdî, vefat ettiği gece Yahya ve Hârûn'u öldürmeye niyetlenmişti. ${ }^{65}$

Hârûn Reşîd, Yahya b. Hâlid b. Bermek'i veziri olarak tayin edince ona, annesi Hayzürân'a danışmadan hiçbir konuda kesin karar vermemesini emretti. Bu emir üzerine devlet işleri Hayzürân'dan habersiz yapılamaz oldu. ${ }^{66}$ Böylece Hayzürân, Hâdî zamanında elinden alınan güç ve itibarını yeniden kazanmış oldu.

Hârûn Reşî̉'in zamanında Abbâsiler en parlak dönemlerinden birini yaşamıştır. Onun zamanında âlimlere ve sanat adamlarına büyük değer verilmiştir. Doğu edebiyatının önemli eserlerinden kabul edilen Binbir Gece Masalları'nın önemli temaları onun zamanına denk gelir. $\mathrm{Bu}$ masallarda anlatılan hikayelerin büyük bir kısmı onun ismi etrafında cereyan ettiği için bu masallar Hârûn Reşîd isminin ölümsüzleşmesine katkıda bulunmuştur. ${ }^{67}$ Hârûn Reşîd üç yıl annesi ile birlikte ülkeyi yönetmiştir. Ağabeyi Hâdî’nin aksine yönetim işlerinde annesine müdahale etmemiş hatta onu sınırsız bir yetki ile donatmıştır.

Mehdî ve Hârûn Reşî̉'in Hayzürân'a güvenmeleri ve ona sınırsız yetki vermeleri acaba devlet yönetimine nasıl yansımıştır? Sözü geçen iki halife döneminde yaşanan istikrarda Hayzürân'ın payı var mıydı? Hatta bu sorulara, eğer Hâdî annesini yönetime dâhil etseydi bu durum onun lehine döner miydi? Annesi ile beraber ülkeyi yönetseydi halifeliğinin ömrünü uzatabilir miydi? gibi soruları da ilave etmek mümkündür. Çalışmamız sırasında gördüğümüz kadarıyla bu sorulara Hayzürân'ın aleyhinde bir cevap vermek zordur. Çünkü Mehdî ve Hârûn Reşîd zamanında kendisine verilen yetkilerin menfî̀ sonuçlarıyla karşılaşmadık. Mehdî ve Hârûn Reşîd, Hayzürân'ın yeteneklerine güvenmiş olmalılar ki bu yüzden onun yetkilerini geniş tutmuşlardır. Kaynaklarda, halkın onun uygulamalarına karşı gösterdiği olumsuz bir tepkiye rastlamadık. Elbette Hâdî döneminde yaşanan çekişme ülkenin istikrarı açısından olumsuz sonuçlar doğurmuştur. Ancak bu çekişmede sadece Hayzürân'1 suçlamak kanaatimizce haksızlık olur. Muhtemelen Hâdî de annesine, babası ve kardeşi gibi davransaydı ülkenin istikrarını devam ettirebilir ve halifeliğinin de ömrünü uzatabilirdi. Nitekim Hâdî’nin, annesini yanına alıp onun gücünden faydalanmak yerine

62 İbn Kesîr, el-Bidâye ve'n-nihâye, 13/557-58.

63 Taberî, Târîhu Taberî, 8/212; İbnü'l-Esîr, el-Kâmil fi't-târîh, 5/272; İbn Kesîr, el-Bidâye ve'n-nihâye, $13 / 557$.

64 İbn Kesîr, el-Bidâye ve'n-nihâye, 13/557; İbnü'l-Cevzî, el-Muntazam, 8/335.

65 Taberî, Târîhu Taberî, 8/230; İbnü'l-Esîr, el-Kâmil fi't-târîh, 5/272; İbn Kesîr, el-Bidâye ve'n-nihâye, $13 / 561$.

66 Taberî, Târîhu Taberî, 8/234; İbn Kesîr, el-Bidâye ve’n-nihâye, 13/562; İbnü'l-Cevzî, el-Muntazam, 8/321; İbn Haldûn, Târîhu İbn Haldûn, 3/273.

67 Apak, Ana Hatlartyla İslâm Tarihi, 131. 
karşısına alması sadece halifeliğinin bir yıl sürmesine neden olmamış aynı zamanda hayatına da mâl olmuştur.

İslam toplumundaki genel anlayışa göre kadın evde oturmalı, kocasına hizmet etmelidir. Sosyal hayatın içinde yer almamalı, belli meslekler dışında çalışma hayatına dâhil edilmemelidir. Bu anlamda Hayzürân sıradışı bir kişilik olarak karşımıza çıkmaktadır. Abbâsî iktidarına doğrudan dâhil olan Hayzürân, düşünülenin aksine ülkede huzur ve sükûnetin sağlanmasına katkı sunmuştur. Elbette bu katkı olmazsa olmaz boyutlarda değildir. Yine kanaatimizce bazı kaynaklar "halife ona danışmadan hiçbir şey yapmamıştır" 68 şeklinde ifadelere yer vererek ona yüklenen yetkiyi abartmışlardır. Biz, onun yönetime katkısının kısmî boyutlarda olduğu görüşündeyiz. Onun yetki alanının bazı atamalarda söz hakkının olması ve saraydaki iç düzenin sağlanması ile sınırlı olduğu kanaatindeyiz. Muhtemelen bu kaynaklar ilk defa bir kadının yönetime dâhil olmasını sıra dışı gördükleri için bu durumu abartılı ifadelerle anlatmışlardır.

Hayzürân, 173/789 yılında Bağdat'ta vefat etti. Cenazesini oğlu Hârûn Reşîd defnetmiştir. Annesinin defni esnasında şu şiiri okuduğu aktarılır: "Bizler zamanın birinde Cüzeyme'nin nedimeleri gibiydik. Öyle beraberdik ki, artık bunlar ayrılmaz deniliyordu... $"$ "69

Kaynaklarda, iki Abbasî halifesinin annesi olarak bu dünyadan ayrılan ${ }^{70}$ Hayzürân'la ilgili Ümmü'l-Veled tabiri kullanılmaktadır. Bu ifade "çocuğun anası, efendisinden çocuk dünyaya getiren cariye" anlamına gelen fikhî bir terimdir. ${ }^{71}$ Halife Mehdî onunla evlendikten sonra Hâdî ve Hârûn Reşîd'i dünyaya getirmiş bu yüzden Ümmü'l-Veled olarak isimlendirilmiştir. ${ }^{72} \mathrm{Bu}$ tabir, bir cariye için büyük bir lütuftur.

Hayzürân'ın neredeyse bir devlet başkanı kadar gelirinin olduğu bildirilmektedir. Çiftliklerinin y1llık gelirinin bir milyon altmış dirhem olduğu rivayet edilmiștir. ${ }^{73}$

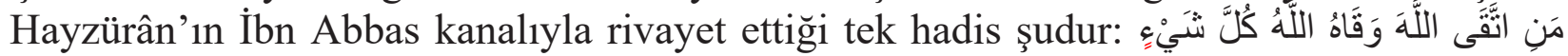
"Allah'tan korkan kimseyi Allah, her şeyden korur."

\section{Sonuç}

Yaklaşık bir asır hüküm süren Emevî halifelerinin eşlerini veya başka kadınları yönetime karıştırmadıklarını görüyoruz. Genel olarak Arap kültüründe hâkim olan yönetim bazında erkek egemenliğinin bu dönemde de varlığını devam ettirdiğini söyleyebiliriz. Nitekim, daha o dönemde hatta daha önceki dönemlerde gerek Bizans devletinde gerekse Sâsânî ülkesinde yer yer kadın hâkimiyetinden söz etmek mümkündür. Emevîler döneminde

68 Taberî, Târîhu Taberî, 8/238; İbnü'l-Cevzî, el-Muntazam,8/348.

69 İbn Kesîr, el-Bidâye ve'n-nihâye, 13/571-72.

70 Taberî, Târîhu Taberî, 8/238; İbn Kesîr, el-Bidâye ve'n-nihâye, 13/569; Mes'ûdî, Mürûcü'ż-zeheb, 3/337; İbnü'l-Cevzî, el-Muntazam, 8/348; Bağdâdî, Târîhu Bă̆dâd, 3/216.

71 Burhâneddin el-Mergīnânî, el-Hidâye, thk. Tallâl Yusuf (Beyrut: Dâru İhyâi’t-turâs el-Arabî, ts.), $2 / 313$.

72 İbn Kesîr, el-Bidâye ve'n-nihâye, 13/570; İbnü'l-Cevzî, el-Muntazam,8/346; Bağdâdî, Târîhu Bă̆dâd, 16/616.

73 İbn Kesîr, el-Bidâye ve'n-nihâye, 13/571-72.

74 İbn Kesîr, el-Bidâye ve’n-nihâye, 13/570; İbnü'l-Cevzî, el-Muntazam, 8/346; Bağdâdî, Târîhu Bağdâd, 16/616. 
ise kadınlar yönetim işlerinden tamamen uzak tutulmuştur. Bunun en önemli sebeplerinden biri Emevî saltanatının Mevâlî’yi ikinci sınıf vatandaş görmesi bu anlayışın neticesinde onları yönetici pozisyonunda değerlendirmemiş olmalarıdır.

Abbâsîler döneminde ise durum değişmiştir. Bu değişimde Mevâlî halkın Abbâsî isyanına destek vermesi etkili olmuştur. İktidarlarını Mevâlî'ye borçlu olduklarının bilincinde olan Abbâsî sultanları artık Arap unsurların dışındaki Müslümanları ilk defa yönetime dâhil etmeye başladılar. Halifeler de bu dönemde Arap olmayan kadınlarla evlenmeye başladılar. Bunların bir kısmı cariye bir kısmı ise hür kadınlardı. İște Hayzürân da Mehdî’ye sunulan cariyelerden biridir. Ancak o, sıradışı bir kişilikti. Güzelliğini ve zekâsını ev işleri yapmak ve kocasına hizmet etmek yerine devleti yönetmede kullanmayı tercih etmiştir. İslam tarihinde yönetime katılma ve insanları yönetme konusunda ilk olması hasebiyle de tarihe geçmiştir. O, aynı zamanda İslam toplumunda hâkim olan kadınların yönetimden uzak tutulması gerektiği genel fikrine tezat davranarak adını tarihe not ettirmiştir. Kocası Mehdî ve oğlu Hârûn Reşîd dönemlerinde kendisine verilen geniş yetkiyi avantaja dönüştürerek bir kadın siyasetçinin de devlet yönetimine katkı sunabileceğini göstermiştir. Onun, oğlu hakkında verdiği infaz emrini savunmamız elbette düşünülemez. Ancak Hayzürân'dan önce oğlu Hâdî’nin annesini zehirletmeye çalışması unutulmamalıdır. Hem zekâsı hem de tedbirli davranması nedeniyle şu an biz oğlunu öldüren Hayzürân'1 konuşuyoruz. Ancak durum tam tersi olabilir ve bizler şu an oğlu tarafindan öldürülen Hayzürân'ı konuşuyor olabilirdik.

Arap kökenli halifelerin devleti yönettiği Emevîler ve Abbâsîler döneminde yüzlerce halife eşi tarih sahnesinden geçmiştir. Bunların sadece bir kısmı hakkında bilgi sahibiyiz. Yüzlerce halife eşinden biri olan Hayzürân'ın da önünde iki seçenek vardı, ya diğer halife eşleri gibi tarihin tozlu sayfalarında kaybolup gidecek ya da tarihin altın sayfalarına ismini yazdıracaktı. Hayzürân, üstün zekâsı ve kabiliyetiyle adından söz ettirmeyi başarmış; cariye olarak girdiği sarayda etkin bir halife eşi olmanın yanında siyasî bir figür olarak da tarihe adını yazdırmıştır.

\section{Kaynakça}

Apak, Âdem. Ana Hatlarıyla İslâm Tarihi, Abbâsîler Dönemi. İstanbul: Ensar Yayinlar1, 2016.

Bağdâdî, Hatîb. Târîhuu Bağdâd, thk. Beşşâr Avâd Ma'rûf. Beyrut: Dâru'l-garbi'lislâmî, $1422 / 2001$.

Güzel, Ahmet. "Mehdî ve Hâdî Dönemleri”. İslam Tarihi ve Medeniyeti. 5: 125. İstanbul: Siyer Yayınları, 2018.

Güzel, Ahmet. "Kadınların Siyasete Etkisi Bağlamında Hayzürân Örneği”. Türk ve İslam Dünyası Sosyal Araştırmalar Dergisi 4/12 (Eylül 2017), 81-91. annesi

Hizmetli, Mustafa. “Abbasiler Döneminde Kadının Siyasetteki Rolü: “Harunürreşid'in 
Hayzuran ve eşi Zübeyde Örneği”. 3. Uluslararası Avrasya Spor Eğitim ve Toplum Kongresi (Kasim 2018, Mardin), 1244-1251.

İbn Abdirabbih, Ebû Ömer Şihâbüddîn Ahmed b. Muhammed. el-İkdü'l-Ferîd. Beyrut: Dâru'l-kütübi'l-ilmiyye, 1404.

İbn Asâkir, Ebü'l-Kāsım. Târîhu Dımeşk. thk. Amr b. Garâme. Dâru'l-fikr, 1415/1995.

İbnü'l-Cevzî, Ebü' l-Ferec Cemaleddin Abdurrahman b. Ali. el-Muntazam fî Târîhi'lÜmem ve'l-Mülûk. thk. Muhammed Abdulkâdir Ata-Mustafa Abdulkâdir Ata. Beyrut: Dârü'l-kütübi'l-ilmiyye, 1412/1992.

İbnü'l-Esîr, Ebü'l-Hasen İzzüddîn Alî b. Muhammed b. Muhammed eş-Şeybânî elCezerî. el-Kâmil fi't-Târîh. thk. Abdullah el-Kâdı. Beyrut: Dâru'l-kütübi'l-ilmiyye, 1415.

İbn Haldûn, Ebû Zeyd Veliyyüddîn Abdurrahmân b. Muhammed b. Muhammed b. Muhammed b. Hasen el-Hadramî el-Mağribî et-Tûnisî. Târîhu İbn Haldûn. thk. Halil Şehâde. Beyrut: Dâru'l-Fikr, 1408/1988.

İbn Hanbel, Ebû Abdillâh Ahmed b. Muhammed b. Hanbel. Müsned. Beyrut: Dâru İhyâu't-turâs el-Arabî, ts.

İbnü'l-İmrânî, Muhammed b. Ali b. Muhammed. el-İnbâü fî Târîhi'l-Hulefâ. thk. Kâsım Sâmirâi. Kâhire: Dâru'l-âfâki'l-arabiyye, 1421/2001.

İbn Kesîr, Ebü'l-Fidâ' İmâdüddîn İsmâîl b. Şihâbiddîn Ömer b. Kesîr b. Dav' b. Kesîr el-Kaysî el-Kureşî el-Busrâvî ed-Dımaşkī. el-Bidâye ve'n-nihâye. thk. Abdullah b. Abdülmuhsin et-Türkî. Dâru Hicr littaba 'ati ve'n-neşri ve’t-tevzî' ve'l-i'lân, 1418/1997.

İbn Kesîr, el-Bidâye ve'n-Nihâye. trc. Mehmet Keskin. İstanbul: Çağrı Yayınları, 1995.

İbn Kuteybe, Ebû Muhammed Abdullāh b. Müslim b. Kuteybe ed-Dîneverî. el-Maârif, thk. Servet Ökkâşe. Kâhire: 1992.

İbn Manzûr, Cemaleddin. Lisânü'l-Arab. Beyrut: Dâru Sâdır, I 1 । .

İbn Tiktaka, Ebû Ca'fer Safiyyüddîn Muhammed b. Alî b. Tabâtabâ el-Hasenî elAlevî. el-Fahrî. Beyrut: Dâru Sâdır, ts.

İbşîhî, Şehabeddin Muhammed. el-Müstețraf. thk. Müfîd Muhammed Kamîha. Beyrut: Dâru'l-kütübi'l-ilmiyye, 1986.

Kırbıyık, Kasım. "Hayzürân". Türkiye Diyanet Vakfı İslâm Ansiklopedisi. 17: 106107. İstanbul: TDV Yayınları, 1998.

Kitapçı, Zekeriya. Abbâsî Hilafeti’nde Selçuklu Hatunları ve Türk Sultanları. Konya: 1997.

Mergīnânî, Burhâneddin. el-Hidâye. thk. Tallâl Yusuf. Beyrut: Dâru İhyâi’t-turâs elArabî, ts.

Mernissi, Fatima. Hanım Sultanlar (İslam Devletlerinde Kadın Hükümdarlar. trc. M. Ali Kayabal-Filiz Nayır. İstanbul: CEP Yayınları, 1992. 
Mes 'ûdî, Ebü’l-Hasen Alî b. el-Hüseyn b. Alî el-Mes'ûdî el-Hüzelî. Mürûcü’ż-zeeheb. thk. Esad Dâgir. Kum: Dâru'l-Hicr, 1409.

Naskoli, Esko. "Sâsânîler". Türkiye Diyanet Vakfi İslâm Ansiklopedisi. 36: 174-176. İstanbul: 2009.

Nicol, Donald M. Bizans'ın Soylu Kadınları. trc. Özden Arıkan. İstanbul: Tarih Vakfı Yurt Yayınları, 2001.

Özdemir, Mehmet Nâdir. “Abbâsîler'de Kölelik”. İslâm Tarihi ve Medeniyeti. 6: 138. İstanbul: Siyer Yayınları, 2018.

Safdî, Salahaddîn Halîl. el-Vâfi bi'l-vefeyât. thk. Ahmet Arnavut ve Türkî Mustafa. Beyrut: Dâru İhyâi't-turâs, 1420/2000.

Süyûtî, Ebü'l-Fazl Celâlüddîn Abdurrahmân b. Ebî Bekr b. Muhammed el-Hudayrî es-Süyûtî. Târîhu'l-Hुulefâ'. thk. Hamdi Timurtaş. Mektebetü Nizâr Mustafa el-Bâz, $1425 / 2004$.

Taberî, Ebû Ca'fer Muhammed b. Cerîr b. Yezîd el-Âmülî et-Taberî el-Bağdâdî. Târîhu Taberî. nşr. Dâru't-Turâs. Beyrut: 1387.

Üçok, Bahriye. İslâm Devletlerinde Türk Nâibeler ve Kadın Hükümdarlar. Bilge Kültür Sanat. 2017.

Ya'kûbî, Ebü'l-Abbâs Ahmed b. Ebî Ya'kūb İshâk b. Ca'fer b. Vehb b. Vâzıh elYa'kūbî. Târîhu Ya'kûbî. Matbaul Berîd, 1883.

Zehabî, Ebû Abdillâh Şemsüddîn Muhammed b. Ahmed b. Osmân ez-Zehebî etTürkmânî el-Fârikī ed-Dımaşkī. Siyeru a lâmi'n-nübelâ'. thk. Şuayp Arnavut liderliğinde bir grup muhakkik. Müessesetü'r-risâle, 1405/1985.

Zehebî, Ebû Abdillâh Şemsüddîn Muhammed b. Ahmed b. Osmân. Târîhu'l-İslâm. thk. Ömer Abdusselam. Beyrut: Dâru'l-kitâbi'l-Arabî, 1413/1993.

Ziriklî, Ebû Gays Muhammed Hayrüddîn b. Mahmûd b. Muhammed b. Alî b. Fâris ez-Ziriklî ed-Dımaşkī. el-A'lâm. Dâru'l-ilm, 2002. 